\title{
Solid-state Fermentation Process for Gibberellin Production Using Enzymatic Hydrolysate Corn Stalks
}

\author{
Jing Bai, ${ }^{\text {a,b,c }}$ Fengli Liu, ${ }^{\text {a,b,c }}$ Siqi Li, ${ }^{\text {a,b,c }}$ Pan Li, ${ }^{\text {a,b,c,* }}$ Chun Chang, ${ }^{\text {a,b,c }}$ and Shuqi Fang a,b,c
}

\begin{abstract}
Solid-state fermentation was carried out for production of gibberellin via the addition of enzymatic hydrolysate from steam-exploded corn stalks during the culture period. The enzymatic hydrolysate from the steamexploded corn stalks was added to the culture medium during the solidstate fermentation period, which improved gibberellin production. When the enzymatic hydrolysate was added into the $400 \mathrm{~mL} / \mathrm{kg}$ dry basis substrate in the solid-state fermentation after $60 \mathrm{~h}$, the temperature was $30^{\circ} \mathrm{C}$, the $\mathrm{pH}$ was 7.00 , the mass ratio of solid to liquid was $1: 1.1$, and the fermentation period was $168 \mathrm{~h}$. This led to the largest gibberellin yield (9.48 $\mathrm{g} / \mathrm{kg}$ dry basis), and when compared with pre-optimization, the gibberellin yield increased by $135 \%$. The optimum conditions to maximize the biomass for the fermentation process were obtained; the temperature was $32{ }^{\circ} \mathrm{C}$ for a gibberellin yield of $9.20 \mathrm{~g} / \mathrm{kg}$ dry basis, the $\mathrm{pH}$ was 6.00 and the mass ratio of solid to liquid was $1: 1.1$ for a gibberellin yield of 9.48 $\mathrm{g} / \mathrm{kg}$ dry basis, and the fermentation period was $96 \mathrm{~h}$ for a gibberellin yield of $6.94 \mathrm{~g} / \mathrm{kg}$ dry basis. Therefore, a new alternative way for gibberellin production via solid-state fermentation has been demonstrated.
\end{abstract}

Keywords: Gibberellin; Solid-state fermentation; Fusarium moniliforme; Steam explosion

Contact information: a: School of Chemical Engineering and Energy, Zhengzhou University, Zhengzhou, Henan 450001, P. R. China; b: Henan Outstanding Foreign Scientists' Workroom, Zhengzhou, Henan 450001, P. R. China; c: Engineering Laboratory of Henan Province for Biorefinery Technology and Equipment, Zhengzhou, Henan 450001, P. R. China; Zhengzhou University, No. 100 of Science Road, Zhengzhou, Henan 450001, P. R. China; *Corresponding author: lipanhust@163.com

\section{INTRODUCTION}

Gibberellins are tetracyclic diterpenoid acid compounds. As an important plant growth regulator, gibberellin is widely used in agriculture, nurseries, horticulture, viticulture, tea plantations, etc. (Martin 1983). It contributes to various efficacies, such as the promotion of stem elongation, germination, and breaking seed dormancy, as well as affecting flowering, gender performance, inhibition of leaf, and fruit aging (Loreto et al. 2008; Dissanayake et al. 2010; Mckenzie and Deyholos 2011). Therefore, the market demand for gibberellin continually increases.

Sawada (1912) pointed out that the overgrowth of rice seedlings could result from fungal infection. Subsequently, Kurosawa (1926) found that rice seedlings and other water grass elongate if the culture filtrate of the dried rice seedlings is used; pathogenic bacteria stimulate the extension of stems but inhibit the formation of chlorophyll and root growth by secreting a compound. Sun (1981) found that the rice bakanae disease was caused by the Fusarium infection, and Teijiro (1934) obtained the effective component from the fermentation filtrate of the pathogen. This component inhibits the growth of rice seedlings under any test concentration, and it was officially named gibberellin in 1935 (Yabuta 1935). Gibberellin produced from fungi is a class of bioactive diterpenoid plant hormones 
(Tudzynski and Hölter 1998). At least 126 types of gibberellin have been identified, which come mainly from plants and microbes (Tudzynski 1999; Shukla et al. 2003).

Gibberellin was first produced via solid-state fermentation in 1988 (Durand and Chereau 1988). The initial liquid fermentation of gibberellin used a liquid surface culture, and then the commonly used process gradually evolved into a liquid medium system, which became the primary production method. Early trials for gibberellin production in Japan were based on surface cultivation with gibberellin yields of $40 \mathrm{mg} / \mathrm{L}$ to $60 \mathrm{mg} / \mathrm{L}$. Before 1961, most submerged fermentation methods had maximum yields of $1 \mathrm{~g} / \mathrm{L}$ of gibberellin (Tudzynski 1999). Lu et al. (1995) investigated the production of gibberellin via immobilized cells fermentation, which exhibited a maximum yield of $210 \mathrm{mg} / \mathrm{L}$ after 84 days and a high level of efficiency. The prototype for a traditional solid-state fermentation was the Koji fermenting process, in which fungus was cultured on grains, such as rice or soy beans (Hesseltine 1977a,b). As early as the 1950s, the solid-state fermentation process has been applied to Fusarium moniliforme (Focke 1967). Gibberellin production levels from solid-state fermentation were found to be 1.6 times higher than that of the deep liquid fermentation with equal amounts of carbon (Kumar and Lonsane 1987). While Gibberella fujikuroi produces $23 \mathrm{mg} / \mathrm{mL}$ of gibberellin in $120 \mathrm{~h}$ via liquid fermentation, a solid-state fermentation process using cassava flour shows higher production $(250 \mathrm{mg} / \mathrm{kg}$ of dry solid media) in a shorter timeframe (Tomasini et al. 1997). Kumar and Lonsane (1987) investigated the influence of the physical and nutritional factors on gibberellic acid production and found that the gibberellin yield was increased 2.9 times via judicious selection of the parameters. In recent years, renewed attention has been given to gibberellins (Li and Sun 2018).

Three stages form the synthetic pathway of gibberellin: stage 1 is the synthesis of Geranylgeranyl diphosphate (GGDP). In stage 2, GGDP is transformed into ga12aldehyde. Stage 3 involves the transformation of ga12-aldehyde into different types of GA. Different culture conditions stimulate the same strain to produce different types of Gibberellins (Hu et al. 2013).

Gibberellin has been produced by these methods using submerged fermentation, but some investigations indicated that a solid-state culture was still necessary, especially for the demands of sustainable development and environmental protection.

Compared with liquid fermentation, solid-state cultures have the following advantages: (1) There is less investment and the process is simpler; (2) There is a high concentration of the end product, leading to simpler and more complete extraction, and the downstream processes are easy and create less pollution in the environment with less water consumption; (3) The fermented raw materials are generally agricultural products, such as bran or maize flour, which are easy obtained; (4) The substrate of the solid culture is easy to adjust according to production demands.

As a large agricultural country, more than 200 million tons of corn stalks are produced each year in China (Wang et al. 2010; Li 2012). However, corn stalks are not fully utilized; most are left idle or burned on the farmland. This process wastes the resources and pollutes the environment. There are multiple pretreatment methods for corn stalks, such as hydrogen peroxide presoaking prior to ammonia fiber expansion (Zhao et al. 2016). Steam explosion technology is a practical method of corn stalk pretreatment (Datar et al. 2007; Elander et al. 2009; Wyman et al. 2009). Corn stalks are more easily hydrolyzed after steam-explosion treatment, and the enzymatic hydrolysate are added as part of the solid-state culture media process. In this paper, the authors investigated the solid-state fermentation process for gibberellin by adding the enzymatic hydrolysate from 
steam-exploded corn stalks. As no methodology had been found in other literature, this work provides a new alternative way to use corn stalks.

\section{EXPERIMENTAL}

\section{Microorganism}

Fusarium moniliforme CICC (China Center of Industrial Culture Collection) 2490 was purchased from the management center of Chinese industrial microbial strain preservation (Chaoyang District, Beijing) in 2015. Fusarium moniliforme was domesticated and improved to adapt to the cultural media, which was added to the enzyme hydrolysate of steam-exploded corn stalks and was named "zzushzxbjlfl50".

Table 1. Reagents Used in the Experiments

\begin{tabular}{|c|c|c|}
\hline Reagent Name & Purity & Manufacturer \\
\hline $\begin{array}{l}\text { Potassium phosphate } \\
\text { monobasic }\end{array}$ & AR & $\begin{array}{l}\text { Tianjin Kermel Chemical Reagent Co., Ltd. } \\
\text { (Tainjin, Hebei, China) }\end{array}$ \\
\hline $\begin{array}{l}\text { Magnesium sulfate } \\
\text { heptahydrate }\end{array}$ & AR & $\begin{array}{l}\text { Guangzhou Chemical Reagent Factory } \\
\text { (Zhaoqing City, Guangdong, China) }\end{array}$ \\
\hline Hydrochloric acid & AR & $\begin{array}{l}\text { Luoyang Haohua Chemical Reagent Co., Ltd. } \\
\text { (Shantou, Guangdong, China) }\end{array}$ \\
\hline Ethyl acetate & AR & $\begin{array}{c}\text { Sinopharm Chemical Reagent Co., Ltd. } \\
\text { (Ningbo, Zhejiang, China) }\end{array}$ \\
\hline Sulfuric acid & AR & $\begin{array}{l}\text { Luoyang Haohua Chemical Reagent Co., Ltd. } \\
\text { (Shantou, Guangdong, China) }\end{array}$ \\
\hline Glucose & AR & $\begin{array}{c}\text { Zhengzhou paini Chemical Reagent Factory } \\
\text { (Zhengzhou, Henan, China) }\end{array}$ \\
\hline Ammonium sulfate & AR & $\begin{array}{l}\text { Tianjin Kermel Chemical Reagent Co., Ltd. } \\
\text { (Tainjin, Hebei, China) }\end{array}$ \\
\hline Sodium hydroxide & AR & $\begin{array}{c}\text { Tianjin Kermel Chemical Reagent Co., Ltd. } \\
\text { (Tainjin, Hebei, China) }\end{array}$ \\
\hline 3,5-Dinitrosalicylic acid & $\mathrm{CP}$ & $\begin{array}{l}\text { Sinopharm Chemical Reagent Co., Ltd. } \\
\text { (Ningbo, Zhejiang, China) }\end{array}$ \\
\hline Sodium tartaric & AR & $\begin{array}{c}\text { Tianjin Fengchuan Chemical Reagent Technology } \\
\text { Co., Ltd. (Tainjin, Hebei, China) }\end{array}$ \\
\hline Phenol & AR & $\begin{array}{l}\text { Luoyang Haohua Chemical Reagent Co., Ltd. } \\
\text { (Shantou, Guangdong, China) }\end{array}$ \\
\hline Anhydrous sodium sulfate & AR & $\begin{array}{l}\text { Laohekou chemical group Co., Ltd. } \\
\text { (Xiangyang, Hubei, China) }\end{array}$ \\
\hline Ethyl alcohol absolute & AR & $\begin{array}{l}\text { Tianjin Fengchuan Chemical Reagent Technology } \\
\text { Co., Ltd. (Tainjin, Hebei, China) }\end{array}$ \\
\hline Sodium citrate & AR & $\begin{array}{l}\text { Tianjin Kermel Chemical Reagent Co., Ltd. } \\
\text { (Tainjin, Hebei, China) }\end{array}$ \\
\hline Citric acid & AR & $\begin{array}{c}\text { Suzhou Chemical Reagents Factory } \\
\text { (Haidian, Beijing, China) }\end{array}$ \\
\hline Augar & $\mathrm{BC}$ & $\begin{array}{c}\text { Tianjin Kermel Chemical Reagent Co., Ltd. } \\
\text { (Tainjin, Hebei, China) }\end{array}$ \\
\hline Trichloroacetic acid solution & AR & $\begin{array}{l}\text { Henan Sanlian science and Trade Co., Ltd. } \\
\text { (Zhengzhou, Henan, China) }\end{array}$ \\
\hline Cellulase & $A R$ & $\begin{array}{l}\text { Novozymes (China) Biotechnology Co., Ltd. } \\
\text { (Tainjin, Hebei, China) }\end{array}$ \\
\hline
\end{tabular}




\section{Corn Stalk Pretreatment}

The corn stalks were sourced from Ye County, Pingdingshan City, Henan Province, China. The pre-treatment process first exploded the corn stalks with steam and then followed with enzymatic treatment. The corn stalks were cut into $3 \mathrm{~cm}$ to $4 \mathrm{~cm}$ long segments and impregnated in water for $24 \mathrm{~h}$, until the mass ratio of corn stalks to water was 1:1. Then the corn stalks were placed into a vessel with a volume-filling coefficient of $30 \%$. Steam was introduced into the vessel until the pressure reached $1.5 \mathrm{MPa}$, and temperature was maintained at $205^{\circ} \mathrm{C}$ for $8 \mathrm{~min}$. Subsequently, the steam was quickly released to standard atmospheric pressure. The corn stalks were broken into small debris during the process. The steam-exploded corn stalks (CSS) were dried to a constant weight at $80{ }^{\circ} \mathrm{C}$ and were stored in the storage room. One $\mathrm{kg}$ of corn stalks and $1.275 \mathrm{~kg}$ of cellulase was added into $352.941 \mathrm{~L}$ of citrate buffer liquid, whose $\mathrm{pH}$ was $4.8 \pm 0.05$. Since $1275 \mathrm{~g}$ of cellulase is equal to $42.5 \mathrm{~mL}$ of cellulase, the enzyme activity was $50 \mathrm{U} / \mathrm{g}$. The hydrolysis flasks were incubated on a shaker at $50{ }^{\circ} \mathrm{C}$ and $200 \mathrm{rpm}$ for $48 \mathrm{~h}$. The supernatant was retained as a matrix ingredient after the enzymatic hydrolysate was centrifuged, which can be abbreviated to SEHC.

The raw materials are commercially available, except for those stated, and the reagents used in the experiments are shown in Table 1.

\section{Culture media}

Table 2 showed the experimental instruments used; vertical pressure steam sterilization pot, visible light spectrophotometer, water bath, electronic analytical balance, artificial climate incubator, incubate the shaker at constant temperature, centrifuge, and steam explosion vessel.

Table 2. The Instruments Used in the Experiments

\begin{tabular}{|c|c|}
\hline Equipment Name & The Product Model and Manufacturer \\
\hline Vertical pressure steam sterilizer & LDZF-30KB-III \\
Shen An Medical (Jiading, Shanghai, China)
\end{tabular}


The slant culture media included $20.00 \mathrm{~g}$ of potatoes, $2.00 \mathrm{~g}$ of glucose, $2.00 \mathrm{~g}$ of agar, $100 \mathrm{~mL}$ of distilled water, and natural $\mathrm{pH}$. The culture media was composed of 120.10 $\mathrm{g} / \mathrm{L}$ of glucose, $4.40 \mathrm{~g} / \mathrm{L}$ of ammonium sulfate, $2.30 \mathrm{~g} / \mathrm{L}$ of potassium dihydrogen phosphate, $4.10 \mathrm{~g} / \mathrm{L}$ of magnesium sulfate heptahydrate, and had a $\mathrm{pH}$ of 4.50 . The solidstate fermentation process was performed in a $250-\mathrm{mL}$ Erlenmeyer flask with a mixture of $5.00 \mathrm{~g}$ wheat bran and $5.00 \mathrm{~g}$ corn flour. This substrate was supplemented with $0.01 \mathrm{~g}$ of potassium dihydrogen phosphate and $0.01 \mathrm{~g}$ of magnesium sulfate.

\section{Experimental procedures}

The domesticated Fusarium moniliforme was inoculated into the slant media and cultured at $28{ }^{\circ} \mathrm{C}$ for 3 to 4 days. Then the hypha of the strain was made into a suspension and the suspension was inoculated into the seed culture medium. Finally, the strain was cultured on a shaker at $28{ }^{\circ} \mathrm{C}$ and $200 \mathrm{rpm}$ for $36 \mathrm{~h}$.

The fermentation conditions were investigated via a single factor experiment, which included the SEHC volume, SEHC adding moment, inoculation quantity, initial $\mathrm{pH}$ of media, mass ratio of solid to liquid, culture temperature, and culture period. $10 \%(\mathrm{w} / \mathrm{v})$ of the seed culture solution was inoculated into the prepared solid fermentation media for the experimental process of the first two factors (Qian et al. 1994). The cultural conditions for the first two factors included the temperature $\left(30{ }^{\circ} \mathrm{C}\right)$, the initial $\mathrm{pH}(7.00)$, the mass ratio of solid to liquid (1:1.1), and the fermentation period (168 h). Each experiment was repeated at least three times.

\section{Analytical Methods}

Determination of glucose content

To detect the glucose content, the DNS (3,5-dinitrosalicylic acid) method was used, as shown by Wang (2002). Table 3 showed the relationship between the glucose content and the $\mathrm{A}_{540}$.

Table 3. Relationship Between the Glucose Contents and the $A_{540}$

\begin{tabular}{|c|c|c|c|c|c|c|c|c|}
\hline Glucose Content $(\mathrm{mg} / \mathrm{mL})$ & 0 & 0.50 & 1.00 & 1.50 & 2.00 & 2.50 & 3.00 & 3.50 \\
\hline$A_{540}$ & 0 & 0.101 & 0.225 & 0.351 & 0.471 & 0.611 & 0.738 & 0.854 \\
\hline
\end{tabular}

The glucose content after enzymatic hydrolysis was $28.00 \mathrm{mg} / \mathrm{mL}$ of SEHC, which was calculated by the glucose standard curve Eq. 1,

$$
y=0.2486 x-0.0162
$$

where $y$ is the absorbance, and $x$ is the concentration.

\section{Determination of gibberellin contents}

To detect the gibberellin content, visible spectrophotography was used (Xiao and Yang 1997). Table 4 shows the relationship between the gibberellin content and the $A_{412}$.

Table 4. Relationship Between the Gibberellin Content and the $A_{412}$

\begin{tabular}{|l|c|c|c|c|c|c|c|}
\hline Glucose Content $(\mathrm{mg} / \mathrm{mL})$ & 0 & 0.315 & 6.25 & 25 & 50 & 100 & 200 \\
\hline $\mathrm{A}_{412}$ & 0 & 0.009 & 0.013 & 0.054 & 0.122 & 0.22 & 0.442 \\
\hline
\end{tabular}


The gibberellin content was calculated by the standard curve Eq. 2,

$$
y=0.0022 x+0.0017
$$

where $y$ is the absorbance, and $x$ is the content.

\section{Determination of dry biomass contents}

In this work, dry biomass referred to the weight of fermented mycelium (Fusarium moniliforme) after being dried. To detect the dry biomass content, the nucleic acid method was used, as shown by Wei et al. (2006). Table 5 showed the relationship between the dry biomass content and the $A_{260}$.

Table 5. Relationship between the Dry Biomass Content and the $A_{260}$

\begin{tabular}{|c|c|c|c|c|c|c|}
\hline Dry Biomass Content $(\mathrm{g})$ & 0 & 0.05 & 0.10 & 0.15 & 0.20 & 0.25 \\
\hline$A_{260}$ & 0 & 0.350 & 0.673 & 0.982 & 1.279 & 1.570 \\
\hline
\end{tabular}

The dry biomass content was calculated by the standard curve Eq. 3,

$$
y=6.255 x+0.027
$$

where $y$ is the absorbance, and $x$ is the quality.

\section{RESULTS AND DISCUSSION}

\section{Effects of the Addition of SEHC to the Culture Media}

In the following experiment, SEHC was added into the fermentation process after $60 \mathrm{~h}$ to accurately compare the effects of SEHC on the gibberellin yield. This time $(60 \mathrm{~h})$ was obtained from earlier experiments.

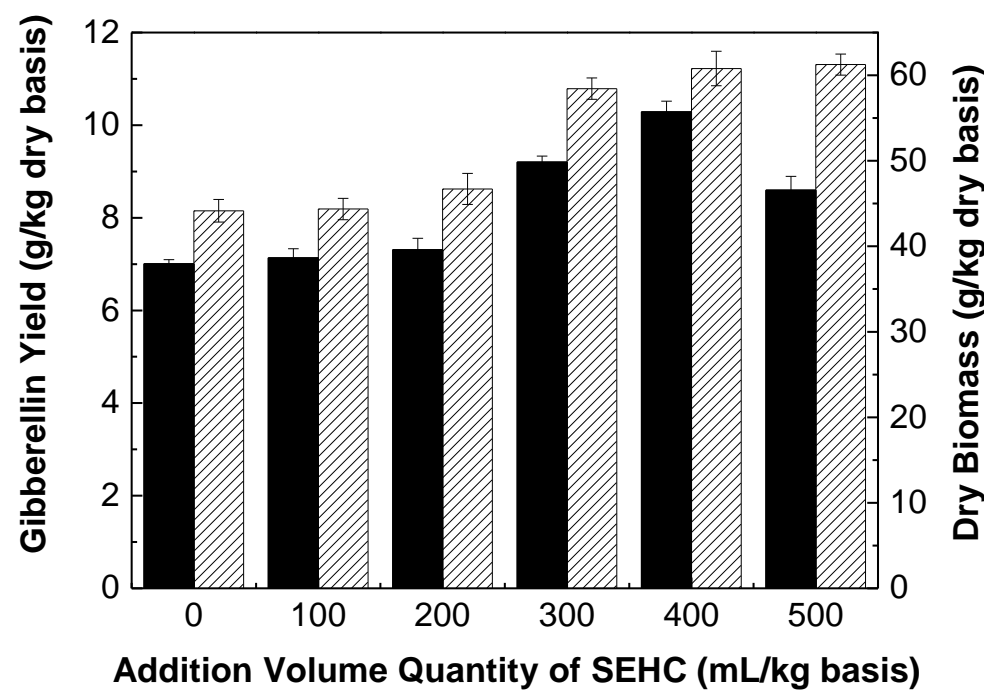

Fig. 1. The gibberellin yield ( $\mathrm{g} / \mathrm{kg}$ dry basis) ( $)$ and the total dry biomass ( $\mathrm{g} / \mathrm{kg}$ dry basis) $(\mathrm{)})$ during solid substrate cultivation with different volumes of SEHC 
The gibberellin yield was investigated using six different addition volumes; 0 $\mathrm{mL} / \mathrm{kg}, 100 \mathrm{~mL} / \mathrm{kg}, 200 \mathrm{~mL} / \mathrm{kg}, 300 \mathrm{~mL} / \mathrm{kg}, 400 \mathrm{~mL} / \mathrm{kg}$, and $500 \mathrm{~mL} / \mathrm{kg}$ of SEHC (dry basis). Figure 1 showed the gibberellin yield and the total dry biomass during solid substrate cultivation with different volumes of SEHC.

As shown in Fig. 1, the gibberellin yield was no more than $8.00 \mathrm{~g} / \mathrm{kg}$ (dry basis) when the volume of the added SEHC was less than $200 \mathrm{~kg} / \mathrm{mL}$ (dry basis). The gibberellin yield increased and then decreased as the volume of SEHC added increased. The lowest gibberellin yield was $7.01 \mathrm{~g} / \mathrm{kg}$ (dry basis) without additional SEHC, and the highest was $9.48 \mathrm{~g} / \mathrm{kg}$ (dry basis) when the added volume of SEHC was $400 \mathrm{~kg} / \mathrm{mL}$ (dry basis). The total dry biomass gradually increased when the volume of the added SEHC increased. Carbon sources were no longer the dominant factor when the volume of the added SEHC was $300 \mathrm{~kg} / \mathrm{mL}$ (dry basis).

The experiment indicated that the addition of small amounts of SEHC cannot meet the demand for carbon sources by the mycelium growth and fermentation process, and excess amounts of SEHC had an inhibitory action on the gibberellin fermentation process.

\section{The Effects of Adding SEHC to the Culture Media at Different Timepoints}

The volume of the added SEHC was $400 \mathrm{~kg} / \mathrm{mL}$ (dry basis) in order to accurately compare different timepoints for the addition of SEHC on the gibberellin yield. The volume of the added SEHC was obtained through earlier experiments.

The gibberellin yield was investigated using five different timepoints to add the SEHC; at 30 h, 45 h, 60 h, 75 h, and $90 \mathrm{~h}$ during the fermentation process. Figure 2 showed the gibberellin yield and the total dry biomass results from the addition of SEHC to the solid substrate cultivation process at different timepoints. It was shown that the gibberellin yield increased and then decreased when the addition of SEHC was delayed. The lowest gibberellin yield was $6.65 \mathrm{~g} / \mathrm{kg}$ (dry basis) at $30 \mathrm{~h}$, and it reached a peak value of $9.48 \mathrm{~g} / \mathrm{kg}$ (dry basis) at $60 \mathrm{~h}$. The total dry biomass gradually increased when the addition of SEHC was delayed. The amount of carbon source available had little effect on the growth of mycelium.

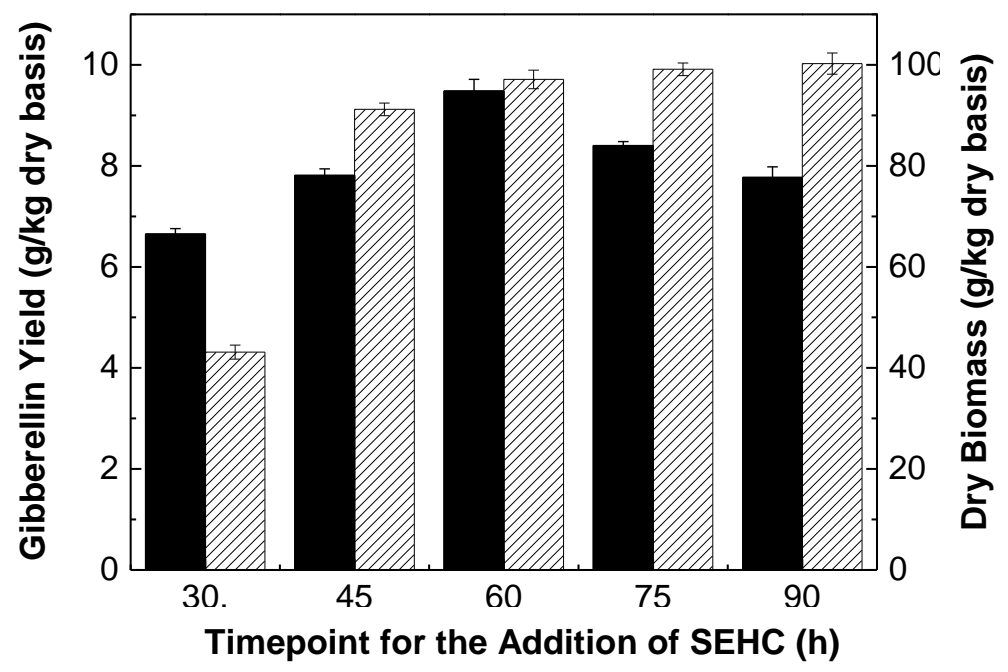

Fig. 2. The gibberellin yield ( $\mathrm{g} / \mathrm{kg}$ dry basis) $(\square$ ) and total dry biomass ( $\mathrm{g} / \mathrm{kg}$ dry basis) $(\mathrm{)})$ during solid substrate cultivation at different timepoints for the addition of SEHC 
The experimental phenomena can be explained by Borrow's theory (Borrow et al. 1964). The gibberellin fermentation process generally experiences five stages, which include the adjustment period, logarithmic growth stage, storage period stage, stable stage, and the last stage. Jiang and Feng (2001) pointed out that the gibberellin yield could be improved when extra carbon sources were added to the culture media in the storage period stage. During this experiment, the $60 \mathrm{~h}$ timepoint happened during the storage period stage. Mao (2017) and Lei et al. (2015) studied the addition of vegetable oil to the gibberellin fermentation process. The results showed that adding vegetable oil after $60 \mathrm{~h}$ could increase the gibberellin yields.

\section{The Effects of the Initial pH}

The effects of the initial $\mathrm{pH}$ on the gibberellin yield were investigated by adjusting the starting $\mathrm{pH}$ to $3.00,4.00,5.00,6.00,7.00,8.00$, or 9.00 for the solid-state fermentation media. The $\mathrm{pH}$ was adjusted through the addition of hydrochloric acid or sodium hydroxide. The conditions for the culture were as follows; the inoculum concentration was $10 \%$, the temperature was $30{ }^{\circ} \mathrm{C}$, the solid to liquid mass ratio was $1: 1.1$, the fermentation period was $168 \mathrm{~h}$, and the enzyme solution was added to the $400 \mathrm{~kg} / \mathrm{mL}$ (dry basis) substrate during the solid-state fermentation process at $60 \mathrm{~h}$.

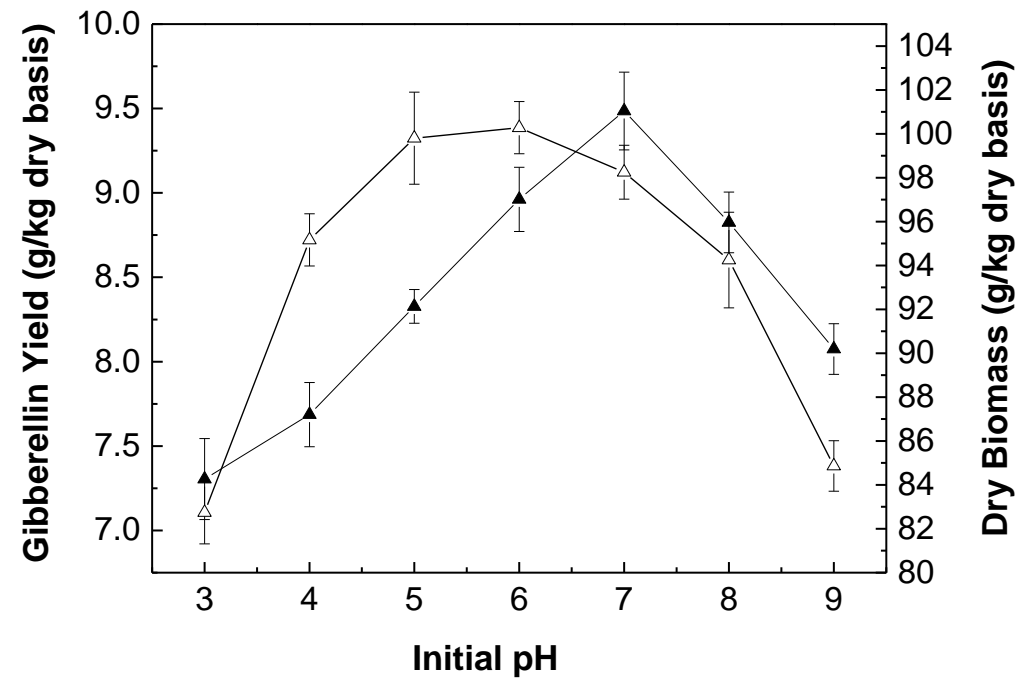

Fig. 3. The gibberellin yield ( $\mathrm{g} / \mathrm{kg}$ dry basis) $(\boldsymbol{\Delta})$ and the total dry biomass ( $\mathrm{g} / \mathrm{kg}$ dry basis) $(\Delta)$ from the solid substrate cultivation process using culture media at different initial pHs

The gibberellin yield and the total dry biomass from the solid substrate cultivation process using culture media at different initial pHs are shown in Fig. 3. It was shown that the gibberellin yield gradually increased and then declined when the $\mathrm{pH}$ was increased from 3.00 to 9.00 . The highest gibberellin yield was $9.48 \mathrm{~g} / \mathrm{kg}$ (dry basis), when the initial $\mathrm{pH}$ was 7.00, and the lowest gibberellin yield was $7.30 \mathrm{~g} / \mathrm{kg}$ (dry basis), when the initial $\mathrm{pH}$ was 3.00. The high gibberellin yields were obtained when the initial $\mathrm{pH}$ was between 6.00 and 8.00 .

The total dry biomass gradually increased and then declined when the $\mathrm{pH}$ was increased from 3.00 to 9.00 . With an initial $\mathrm{pH}$ of 6.00 , the total dry biomass was the highest, $100.3 \mathrm{~g} / \mathrm{kg}$ (dry basis), and the gibberellin yield was $8.96 \mathrm{~g} / \mathrm{kg}$ (dry basis). When 
the initial $\mathrm{pH}$ was 3.00 , the total dry biomass was the lowest, $82.7 \mathrm{~g} / \mathrm{kg}$ (dry basis), and the gibberellin yield was also the lowest. The experimental phenomena can be explained by the fact that the activity of many enzymes associated with microbial cell metabolism are often affected by the $\mathrm{pH}$ level. A high or a low $\mathrm{pH}$ value made it difficult for the fungus to grow, therefore, a $\mathrm{pH}$ of 7.00 was the most appropriate.

\section{The Effects of the Solid to Liquid Ratio}

Different solid to liquid mass ratios for the culture media were investigated: 1:0.7, $1: 0.9,1: 1.1,1: 1.3$, and $1: 1.5$. The conditions for the culture were as follows; the inoculum concentration was $10 \%$, the temperature was $30{ }^{\circ} \mathrm{C}$, the initial $\mathrm{pH}$ was 7.00 , the fermentation period was $168 \mathrm{~h}$, and the enzyme solution was added to the $400 \mathrm{~kg} / \mathrm{mL}$ (dry basis) substrate during the solid-state fermentation process at $60 \mathrm{~h}$. It was found that the gibberellin yield increased and then decreased as the mass ratio increased, as shown in Fig. 4. The highest gibberellin yield was $9.48 \mathrm{~g} / \mathrm{kg}$ (dry basis), when the solid to liquid mass ratio was $1: 1.1$, and the lowest gibberellin yield was $2.72 \mathrm{~g} / \mathrm{kg}$, when the solid to liquid mass ratio was 1:0.7

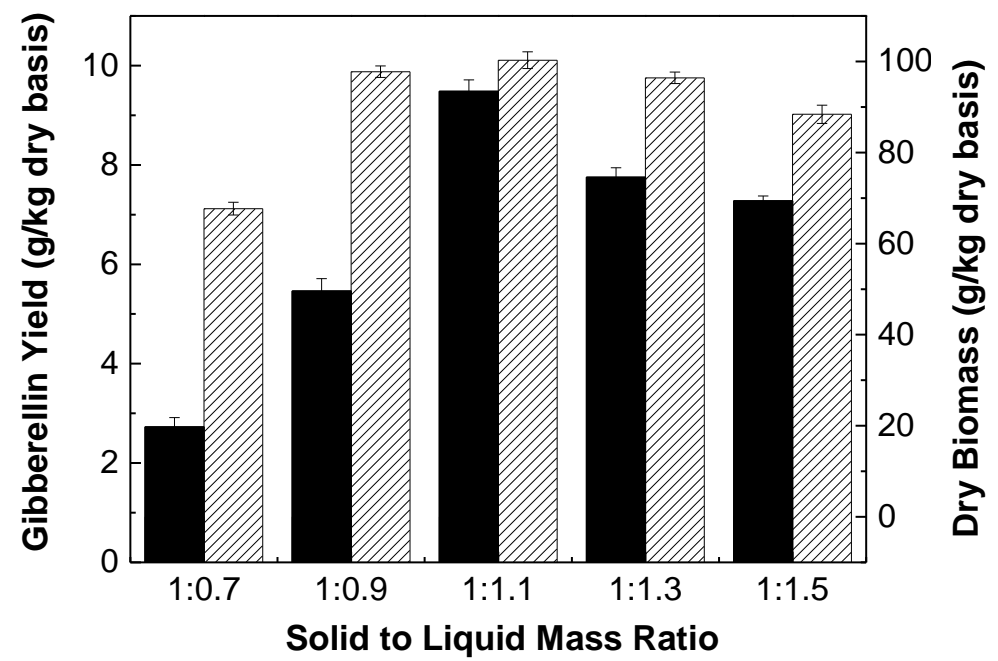

Fig. 4. The gibberellin yield ( $\mathrm{g} / \mathrm{kg}$ dry basis) ( ) and the total dry biomass ( $\mathrm{g} / \mathrm{kg}$ dry basis) $(\mathrm{)})$ from the solid substrate cultivation process at different solid to liquid mass ratios

\section{The Effects of the Culture Temperature}

The effects of the temperature during the solid-state fermentation process were investigated by varying the fermentation temperature to $26^{\circ} \mathrm{C}, 28{ }^{\circ} \mathrm{C}, 30{ }^{\circ} \mathrm{C}, 32{ }^{\circ} \mathrm{C}$, and $34{ }^{\circ} \mathrm{C}$. The conditions for the culture were as follows; the inoculum concentration was $10 \%$, the solid to liquid mass ratio was $1: 1.1$, the initial $\mathrm{pH}$ was 7.00 , the fermentation period was $168 \mathrm{~h}$, and the enzyme solution was added to the $400 \mathrm{~kg} / \mathrm{mL}$ (dry basis) substrate during the solid-state fermentation process at $60 \mathrm{~h}$. Figure 5 shows the gibberellin yield and the total dry biomass during the solid substrate cultivation process at different culture temperatures. The gibberellin yield increased and then decreased as the culture temperature increased. The highest gibberellin yield was $9.48 \mathrm{~g} / \mathrm{kg}$ (dry basis), when the culture temperature was $30^{\circ} \mathrm{C}$, and the lowest gibberellin yield was $8.03 \mathrm{~g} / \mathrm{kg}$ (dry basis), when the culture temperature was $26^{\circ} \mathrm{C}$. 


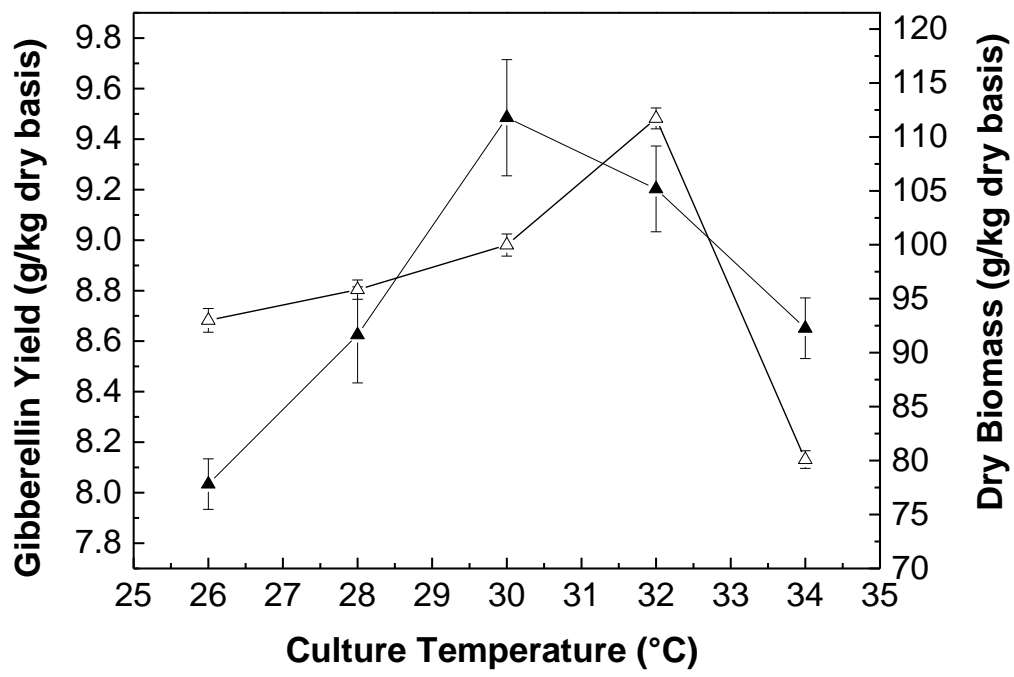

Fig. 5. The gibberellin yield ( $\mathrm{g} / \mathrm{kg}$ dry basis) $(\boldsymbol{\Delta})$ and the total dry biomass ( $\mathrm{g} / \mathrm{kg}$ dry basis) $(\Delta)$ during the solid substrate cultivation process at different culture temperatures.

The total dry biomass gradually increased and then started to decline when the culture temperature was increased. When the culture temperature was $32{ }^{\circ} \mathrm{C}$, the largest total dry biomass was $111.7 \mathrm{~g} / \mathrm{kg}$ (dry basis) and the gibberellin yield was $9.20 \mathrm{~g} / \mathrm{kg}$ (dry basis). When the culture temperature was $26^{\circ} \mathrm{C}$, the lowest total dry biomass was $93.0 \mathrm{~g} / \mathrm{kg}$ (dry basis) and the gibberellin yield was $8.65 \mathrm{~g} / \mathrm{kg}$ (dry basis).

A culture temperature between $28{ }^{\circ} \mathrm{C}$ to $32{ }^{\circ} \mathrm{C}$ benefited mycelium growth and gibberellin fermentation. The lag period stage is lengthened when the temperature was low, and therefore, the gibberellin yield decreased due to the length of the hyphal growth stage. The lag period stage length decreased, as well as the stable stage length, when the temperature was high, which led to a decrease in gibberellin yield (Wang et al. 2017).

\section{The Investigation of the Optimal Gibberellin Culture Period}

In this work, the optimal total length for the gibberellin culture process was investigated. The conditions for the culture were as follows; the inoculum concentration was $10 \%$, the solid to liquid mass ratio was $1: 1.1$, the initial $\mathrm{pH}$ was 7.00 , the temperature was $30{ }^{\circ} \mathrm{C}$, and the enzyme solution was added to the substrate of $400 \mathrm{~kg} / \mathrm{mL}$ (dry basis) substrate during the solid-state fermentation process at $60 \mathrm{~h}$. The gibberellin yield gradually increased at first and then sharply increased before plateauing as the culture time increased, as shown in Fig. 6. The peak gibberellin yield was $9.48 \mathrm{~g} / \mathrm{kg}$ (dry basis) after $168 \mathrm{~h}$ and maintained as the culture time increased. The total dry biomass sharply increased before plateauing, and then slightly decreasing as the culture temperature increased. When the total culture time was $96 \mathrm{~h}$, the largest total dry biomass was $100.3 \mathrm{~g} / \mathrm{kg}$ (dry basis) and the gibberellin yield was $6.94 \mathrm{~g} / \mathrm{kg}$ (dry basis). The mycelium primarily grew when the total culture time was between $0 \mathrm{~h}$ to $48 \mathrm{~h}$. The gibberellin was primarily produced by Fusarium moniliforme when the culture time was between $48 \mathrm{~h}$ to $150 \mathrm{~h}$. The nutrients had been consumed by the mycelium and then broke into smaller parts, or melted, when the mycelium grew until $168 \mathrm{~h}$. 


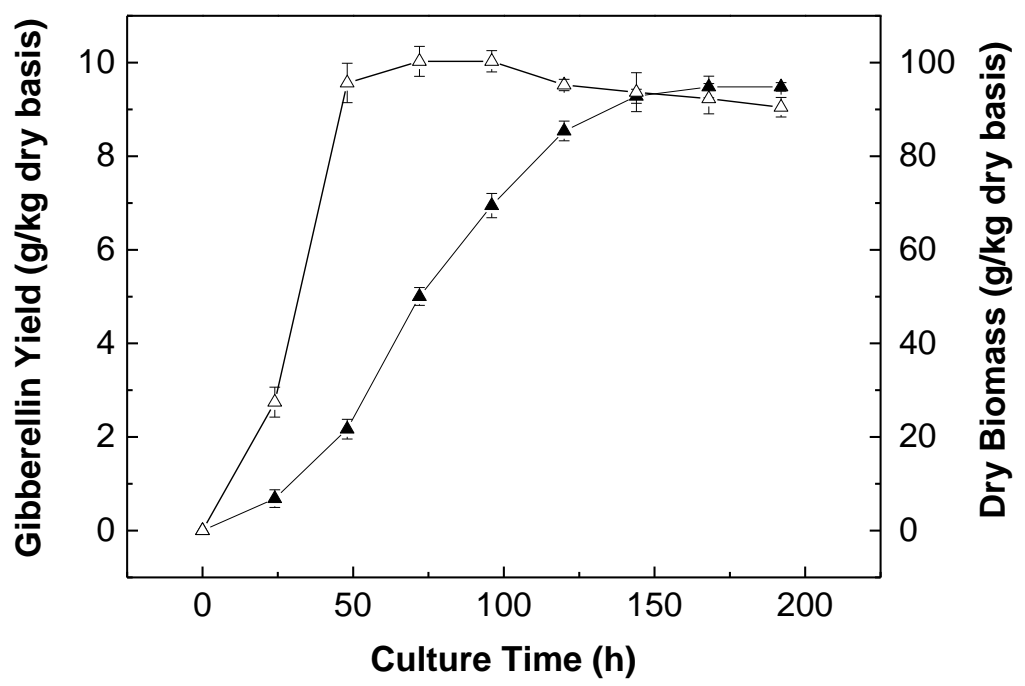

Fig. 6. The gibberellin yield ( $\mathrm{g} / \mathrm{kg}$ dry basis) ( $\boldsymbol{\Delta}$ ) and the total dry biomass ( $\mathrm{g} / \mathrm{kg}$ dry basis) $(\Delta)$ during the solid substrate cultivation process at different culture times

\section{Comparison with the Experimental Results}

To verify the feasibility of the experiment, a large amount of literature was read, and relatively high gibberellin yields were selected to compare. The experimental results of this study and other literatures are shown in Table 6. The data indicate that the peak gibberellin yield was slightly less than documented by Yang (1994) at optimum conditions; however, it was higher than submerged fermentation. The peak gibberellin yield was not the highest one when compared to the literature; but it provided a new alternative method for gibberellin production via solid-state fermentation with the utilization of biomass considered as well.

Table 6. Comparison of Experimental Results and Previous Reports

\begin{tabular}{|c|c|c|c|}
\hline $\begin{array}{c}\text { Peak Gibberellin } \\
\text { Yield }\end{array}$ & Fermentation Mode & $\begin{array}{c}\text { Raw Data of Peak } \\
\text { Gibberellin Yield }\end{array}$ & Reference \\
\hline $9.48 \mathrm{~g} / \mathrm{kg}$ (dry basis) & $\begin{array}{c}\text { Solid-state } \\
\text { fermentation }\end{array}$ & $9.48 \mathrm{~g} / \mathrm{kg}$ (dry basis) & This study \\
\hline $9.69 \mathrm{~g} / \mathrm{kg}$ (dry basis) & $\begin{array}{c}\text { Solid-state } \\
\text { fermentation }\end{array}$ & $9693 \mu \mathrm{g} / \mathrm{g}$ (dry basis) & (Yang Jiahua 1994) \\
\hline $5.80 \mathrm{~g} / \mathrm{kg}$ (dry basis) & $\begin{array}{c}\text { Solid-state } \\
\text { fermentation }\end{array}$ & $5.8 \mathrm{~g} / \mathrm{kg}$ (dry basis) & $\begin{array}{c}\text { (Rodrigues } \text { et al. } \\
\text { 2009) }\end{array}$ \\
\hline $7.80 \mathrm{~g} / \mathrm{kg}$ (dry basis) & $\begin{array}{c}\text { Solid-state } \\
\text { fermentation }\end{array}$ & $7.8 \mathrm{mg} / \mathrm{g}$ (dry basis) & (Satpute et al. 2010) \\
\hline $1.48 \mathrm{~g} / \mathrm{L}$ & $\begin{array}{c}\text { Submerged } \\
\text { fermentation }\end{array}$ & $1480 \mu \mathrm{g} / \mathrm{mL}$ & (Zhuang et al. 2008) \\
\hline $0.38 \mathrm{~g} / \mathrm{L}$ & $\begin{array}{c}\text { Submerged } \\
\text { fermentation }\end{array}$ & $380 \mathrm{mg} / \mathrm{L}$ & $\begin{array}{c}\text { (Rios-Iribe et al. } \\
\text { 2011) }\end{array}$ \\
\hline
\end{tabular}




\section{CONCLUSIONS}

1. In this work, the solid-state fermentation process for gibberellin via the addition of enzymatic hydrolysate from steam-exploded corn stalks was investigated.

2. The optimum conditions for the culture were as follows; a temperature of $30^{\circ} \mathrm{C}$, an initial $\mathrm{pH}$ of 7.00, a solid to liquid mass ratio of 1:1.1, a fermentation period of $168 \mathrm{~h}$, and an enzyme solution of $400 \mathrm{~kg} / \mathrm{mL}$ (dry basis) was added to the substrate during the solid-state fermentation process at $60 \mathrm{~h}$.

3. The optimum conditions for the fermentation process were as follows; a temperature of $32^{\circ} \mathrm{C}$ had a gibberellin yield of $9.20 \mathrm{~g} / \mathrm{kg}$ (dry basis), a pH of 6.00 had a gibberellin yield of $8.96 \mathrm{~g} / \mathrm{kg}$ (dry basis), a solid to liquid mass ratio of 1:1.1 had a gibberellin yield of $9.48 \mathrm{~g} / \mathrm{kg}$ (dry basis), and a fermentation period of $96 \mathrm{~h} \mathrm{had}$ a gibberellin yield of $6.94 \mathrm{~g} / \mathrm{kg}$ (dry basis).

4. In contrast with previous reports, the peak gibberellin yield in this work was close to the maximum value in the previous literatures. It provided a new alternative method for gibberellin production via solid-state fermentation in addition to considering the application of corn stalks.

\section{ACKNOWLEDGEMENTS}

This work was supported by the Henan Science and Technology Think-tank Project (No. HNKJZK-2019-20B); the Tackle Key Problem in Science and Technology of Zhengzhou Municipal Science and Technology Bureau (141PPTGG409); the China Postdoctoral Science Foundation (No. 2018M632800); the Key Research Projects of Henan Colleges and Universities (No. 19A470009); the Henan Provincial Key R\&D and Promotion Project (No. 192102210080); and the Program of Henan Center for Outstanding Overseas Scientists (No. GZS2018004).

\section{REFERENCES CITED}

Borrow, A., Brown, S., Jefferys, E. G., Kessell, R. H. J., Lloyd, E. C., Lloyd, P. B., Rothwell, A., Rothwell, B., and Swait, J. C. (1964). "The kinetics of metabolism of Gibberella fujikuroi in stirred culture," Canadian Journal of Microbiology 10, 445. DOI: $10.1139 / \mathrm{m} 64-055$

Datar, R., Huang, J., Maness, P. C., Mohagheghi, A., Czernik, S., and Chornet, E. (2007). "Hydrogen production from the fermentation of corn stover biomass pretreated with a steam-explosion process," International Journal of Hydrogen Energy 32, 932-939. DOI: 10.1016/j.ijhydene.2006.09.027

Dissanayake, P., George, D. L., and Gupta, M. L. (2010). "Effect of light, gibberellic acid and abscisic acid on germination of guayule (Parthenium argentatum gray) seed," Industrial Crops and Products 32(2), 111-117. DOI: 10.1016/j.indcrop.2010.03.012 
Durand, A., and Chereau, D. (1988). "A new pilot reactor for solid-state fermentation: Application to the protein enrichment of sugar beet pulp," Biotechnology and Bioengineering 31, 476-86. DOI: 10.1002/bit.260310513

Elander, R. T., Dale, B. E., Holtzapple, M., Ladisch, M. R., Lee, Y. Y., Mitchinson, C., Saddler, J. N., and Wyman, C. E. (2009). "Summary of findings from the biomass refining consortium for applied fundamentals and innovation (CAFI): Corn stover pretreatment," Cellulose 16, 649-659. DOI: 10.1007/s10570-009-9308-y

Focke, I. S. G. S. (1967). "Der Einflu komplexer Nahrsubstrate auf die Gibberellin Bildung von Fusarium moniliforme [The influence of complex food substrates on the gibberellin formation of Fusarium moniliforme]," Sheld Biol. Zentralbl 86, 509.

Hesseltine, C. W. (1977a). "Solid state fermentation," Process Biochemistry 12, 24-27. Hesseltine, C. W. (1977b). "Solid state fermentation," Process Biochemistry 12, 29-32. Jiang, L., and Feng, Y. (2001). "Research on the separation and extraction of the solid state of gibberellin," Journal of Southwest Normal University (Natural Science) 26, 323-328.

Kumar, P. K., and Lonsane, B. K. (1987). "Gibberellic acid by solid state fermentation: Consistent and improved yields," Biotechnology and Bioengineering 30, 267. DOI: 10.1002/bit.260300217

Kurosawa, E. (1926). "Experimental studies on the nature of the substance secreted by the bakanae fungus," Natural History Society of Formosa, pp. 213-227.

Lei, W., Liang, Q., and Liao, H. (2015). "Effects of gibberellin 978 strains on the fermentation of GA3," Agriculture and Technology 35, 2.

Li, A., and Sun, L. (2018). "From gibberellin to farm chemical 920: The advancement of a plant hormone in China during 1950-1970s," Ancient and Modern Agriculture 1, $15-22$.

Loreto, P., Claudia, B., and Thomas, F. (2008). "Effect of plant growth regulators on floral differentiation and seed production in jojoba (Simmondsia chinensis (Link) Schneider)," Industrial Crops and Products 27(1), 44-49. DOI: 10.1016/j.indcrop.2007.07.001

Lu, Z. X., Xie, Z. C., and Kumakura, M. (1995). "Production of gibberellic acid in Gibberella fujikuroi adhered onto polymeric fibrous carriers," Process Biochemistry 30, 661-665. DOI: 10.1016/0032-9592(94)00042-5

Mao, Y. (2017). "Analysis of the effect of vegetable oil on the fermentation of gibberellin $\mathrm{GA}_{3}, "$ Exchange Field 48, 193.

Martin, C. G. (1983). "The biochemistry and physiology of gibberellins," in: Gibberellins, A. Crozier (ed.), Praeger Publishers, New York, NY, pp. 395-411.

McKenzie, R. R., and Deyholos, M. K. (2011). "Effects of plant growth regulator treatments on stem vascular tissue development in linseed (Linum usitatissimum L.)," Industrial Crops and Products 34(1), 1119-1127. DOI:10.1016/j.indcrop.2011.03.028

Qian, X. M., Du, P. J., and Kilian, S. G. (1994). "Factors affecting gibberellic acid production by Fusarium moniliforme in solid-state cultivation on starch," World Journal of Microbiology and Biotechnology 10, 93-99. DOI: 10.1007/BF00357571

Rios-Iribe, E. Y., Flores-Cotera, L. B., Chávira, M. M. G., González-Alatorre, G., and Escamilla-Silva, E. M. (2011). "Inductive effect produced by a mixture of carbon source in the production of gibberellic acid by Gibberella fujikuroi," World Journal of Microbiology and Biotechnology 27, 1499-1505. DOI:10.1007/s11274-010-0603-4 
Rodrigues, C., Vandenberghe, L. P. D. S., Teodoro, J., Oss, J. F., Pandey, A., and Soccol, C. R. (2009). "A new alternative to produce gibberellic acid by solid state fermentation," Brazilian Archives of Biology and Technology 52, 181-188. DOI: 10.1590/S1516-89132009000700023

Satpute, D., Sharma, V., Murarkar, K., Bhotmange, M., Dharmadhikari, D., Kumar, S., Mukherjee, S., and Fan, M. H. (2010). "Solid-state fermentation for production of gibberellic acid using agricultural residues," International Journal of Environment and Pollution 43, 201-213. DOI: 10.1504/IJEP.2010.035924

Sawada, K. (1912). "Diseases of agricultural products in Japan," Formosan Agricultural Reviews 63, 10-16.

Shukla, R., Srivastava, A. K., and Chand, S. (2003). "Bioprocess strategies and recovery processes in gibberellic acid fermentation," Biotechnology and Bioprocess Engineering 8, 269-278. DOI: 10.1007/BF02949216

Sun, S. K. S. W. (1981). "The bakanae disease of the rice plant," in: Fusarium Disease, B. A. Torry, P. E. Nelson, T. A. Toussoun, and R. J. Cook (eds.), The Pennsylvania State University Press, University Park, PA, pp. 104-113.

Tomasini, A., Fajardo, C., and Barrios-Gonza Lez, J. (1997). “Gibberellic acid production using different solid-state fermentation systems," World Journal of Microbiology and Biotechnology 13, 203-206.

Tudzynski, B. (1999). "Biosynthesis of gibberellins in Gibberella fujikuroi: Biomolecular aspects," Applied Microbiology and Biotechnology 52, 298-310. DOI: $10.1007 / \mathrm{s} 002530051524$

Tudzynski, B., and Hölter, K. (1998). "Gibberellin biosynthetic pathway in Gibberella fujikuroi: Evidence for a gene cluster," Fungal Genetics and Biology 25, 157-170. DOI: 10.1006/fgbi.1998.1095

Wang, X. (2002). Principles and Methods of Biochemical Experiment, China Agricultural Press, Beijing, China.

Wang, P., Li, X., Yuan, H., and Pang, Y. (2010). “Anaerobic biogasification performance of corn stalk pretreated by a combination of green oxygen and $\mathrm{NaOH}$," Journal of Beijing University of Chemical Technology 37, 115-118.

Wang, W., Wu, Y., Li, J., and Yao, Y. (2017). "Effects of temperature on the fermentation of gibberellin and optimization strategy," Chinese Journal of Applied and Environmental Biology 23, 432-436.

Wei, P., Cen, P., and Sheng, C. (2006). "Comparison of three methods for the determination of biomass in solid state fermentation," Journal of Food and Biotechnology 25, 60-64.

Wyman, C. E., Dale, B. E., Elander, R. T., Holtzapple, M., Ladisch, M. R., Lee, Y. Y., Mitchinson, C., and Saddler, J. N. (2009). "Comparative sugar recovery and fermentation data following pretreatment of poplar wood by leading technologies," Biotechnology Progress 25, 333. DOI: 10.1002/btpr.142

Xiao, Z., and Yang, J. (1997). "Spectrophotometric determination of gibberellin," Journal of Yantai University (Natural Science and Engineering) 10, 266-268. DOI:

Yabuta, T. (1935). "Biochemistry of the "bakanae" fungus of rice," Biological Agriculture \& Horticulture 10, 17-22.

Yang, J., and Xiao, Z. (1994). "The solid fermentation nutrition model of gibberellin," Journal of Yantai University (Natural Science and Engineering) 27-28.

Zhao, C., Shao, Q., Ma, Z., Li, B., and Zhao, X. (2016). "Physical and chemical characterizations of corn stalk resulting from hydrogen peroxide presoaking prior to 
ammonia fiber expansion pretreatment," Industrial Crops and Products 83(2), 86-93. DOI: $10.1016 /$ j.indcrop.2015.12.018

Zhuang, M., Wang, J., Ji, Z., and Chen, S. (2008). "The effect and analysis of vegetable oil on the fermentation of gibberellic acid," Journal of the Chinese Cereals and Oils Association 23, 77-80.

Article submitted: June 26, 2019; Peer review completed: September 2, 2019; Revised version received: November 18, 2019; Accepted: November 19, 2019; Published:

November 26, 2019.

DOI: $10.15376 /$ biores.15.1.429-443 